\title{
HOME OFFICE - PRÁCE NA DÁLKU DLE PODMÍNEK § 317 ZÁKONÍKU PRÁCE
}

\author{
JAKUB HABLOVIČ
}

\begin{abstract}
Home Office - Distance Working according to the Conditions of $\S 317$ of the Labour Code

The article deals with the issue of performing dependent work according to the conditions of $\S 317$ of the Labour Code which is most often referred to as home office. Because such a designation is not used by law, this article deals with the comparison of the terms that are used for this legal institute and determines the basic criteria for its precise definition. In the following sections, the article deals with the issue of the place of performing dependent work as a basic feature of this institute, and describes and analyzes the limits of its legal adjustment. It focuses on the issue of OHS, accidents at work, remuneration and other situations which are possible limitations in application in practice.
\end{abstract}

Keywords: law; labor law; home office; distant performance of dependent work; OHS; work accident

Klíčová slova: právo; pracovní právo; home office; distanční výkon závislé práce; BOZP; pracovní úraz

DOI: $10.14712 / 23366478.2021 .10$

\section{ÚVOD}

Práce na dálku je v současné situaci rozvíjejícího se trendu atypických pracovněprávních vztahů ${ }^{1}$ stále diskutovanějším tématem, a to nejen díky probíhající pandemii nemoci covid-19. Při obsazování nových pracovních míst bylo za posledních 10 let uzavřeno více než $50 \%$ pracovněprávních vztahů v EU tímto způsobem. ${ }^{2} \mathrm{Na}$

1 Výklad tohoto pojmu je v literatuře různě široce pojímán. K této problematice výzkumná studie „The Employment Status of Individuals in Non-Standard by Employment“, jejímiž autory jsou B. Burchill, S. Deakin a S. Honey z Ministerstva obchodu a průmyslu Velké Británie (UK Department of Trade and Industry, 1999), označuje za nestandardní formy zaměstnání ,takové podmínky práce, které se odchylují od modelu ,stálého ' pracovního poměru neboli pracovního poměru na dobu neurčitou, jenž je založen na nepřetržité práci na plný úvazek v průběhu celého týdne "(Komise evropských společenství. Zelená kniha. Modernizace pracovního práva, jejímž cílem je řešit výzvy 21. století. KOM(2006) 708 v konečném znění [online]. 2006, s. 3 [cit. 2019-11-30]. Dostupné na: http://www.europarl.europa.eu/meetdocs/2004_2009 /documents/com/com_com(2006)0708_/com_com(2006)0708_cs.pdf); nebo Hůrka, P. Flexibilní formy zaměstnání. In: PICHRT, J. - MORÁVEK, J. (eds.). Atypická zaměstnání - cesta k vy̌šš zaměstnanosti? Praha: Wolters Kluwer, 2015, s. 77-78.

2 Evropská komise. Návrh Směrnice evropského parlamentu a rady o transparentních a předvídatelných pracovních podmínkách v Evropské unii [online]. 2017, s. 1 [cit. 2019-11-30]. Dostupné na: https://eur-lex .europa.eu/legal-content/CS/TXT/PDF/?uri=CELEX:52017PC0797\&from=CS. 
tento trend muselo s předstihem reagovat pracovní právo vytvořením právního prostředí, které by tyto formy pracovněprávních vztahů umožňovalo.

Na evropské úrovni již v roce 2001 byli sociální partneři Evropskou radou vyzváni, aby v souladu s Evropskou strategií zaměstnanosti jednali o modernizaci organizace práce, včetně pružných forem práce. Výsledkem těchto jednání byla Rámcová dohoda o práci na dálku, která byla podepsána v Bruselu 16. 7. 2002 evropskými sociálními partnery ETUC, UNICE/UEAPME a CEEP. Tato dohoda měla za cíl vytvořit všeobecný rámec na evropské úrovni, který budou implementovat členové signatářských stran v souladu s národními mechanismy a praxí specifickou pro řízení a práci.

V dohodě je používán pojem práce na dálku, který je v rámci ní definován jako forma organizace a výkonu práce, využívající informačních technologií v kontextu pracovní smlouvy, kdy závislá práce, která by mohla být také vykonávána v prostorách zaměstnavatele, je prováděna mimo tyto prostory, a dále pojem pracovník na dálku, který je definován jako každá osoba provádějící práci na dálku. Základní zásadou dohody je, že stejných práv garantovaných př́íslušnou legislativou a kolektivními smlouvami, jaké požívá pracovník pracující v prostorách zaměstnavatele, musí požívat i pracovník na dálku, při zohlednění zvláštnosti práce na dálku.

Dohoda dále rozvádí charakter práce na dálku a některé její aspekty, např̀.: charakter práce na dálku je dobrovolný a předpokládá možnost, aby byla tato forma organizace a výkonu práce sjednána; zaměstnavatel musí respektovat soukromí pracovníka na dálku; za poskytnutí, instalaci a údržbu zařízení nezbytných při práci je odpovědný zaměstnavatel, pokud zaměstnanec nepoužívá vlastní; zaměstnavatel nese náklady, které s prací na dálku souvisejí, např. náklady na komunikaci; za BOZP pracovníků na dálku je odpovědný zaměstnavatel; pracovník na dálku si organizuje svoji pracovní dobu.

Práce na regulaci pružných forem práce na evropské úrovni pokračovala i nadále. Aktuálně Evropská komise vydala návrh Směrnice o transparentních a předvídatelných pracovních podmínkách v Evropské unii. ${ }^{3}$ Jedním z hlavních cílů směrnice je omezení nestability a nedostatku předvídatelnosti, které sebou nese zvýšená flexibilita atypických pracovněprávních vztahů.

Návrh mimo jiného navrhuje zlepšit pracovní podmínky všech pracovníků, především těch pracujících v nových a nestandardních formách zaměstnání, včetně práce na dálku, a současně zachovat prostor pro přizpůsobivost a inovace trhu práce, zvýšit transparentnost na trhu práce a zároveň zabránit uložení nadměrné zátěže pro podniky všech velikostí. Návrh však sám přiznává, že ztratí drobnou část flexibility. Na rozdíl od předchozích regulačních snah návrh koncipuje směrnici jako obecnější s odůvodněním, že národní úpravy budou mít širší možnost zvolit vhodné nástroje regulace. Dopad této nové regulace na práci na dálku bude záviset na tom, jakým způsobem český zákonodárce obecná pravidla směrnice uchopí, ale už ted’ lze říci, že bude klást na zaměstnavatele nové podmínky, které ještě více ztíží praktickou využitelnost práce na dálku.

České pracovní právo na tento trend práce na dálku také reagovalo, i když pro něj nebyl úplnou novinkou. Zákon č. 65/1965 Sb., zákoník práce (starý), již od roku 1966

Směrnice by měla nahradit směrnici Rady 91/533/EHS ze dne 14. října 1991 o povinnosti zaměstnavatele informovat zaměstnance o podmínkách pracovní smlouvy nebo pracovního poměru, s tím, že její působnost by měla být roztažena i na atypické pracovněprávní vztahy. 
v ustanovení § 267 odst. 2 upravoval tzv. domáckého zaměstnance, který byl definován jako zaměstnanec, který nepracuje na pracovišti zaměstnavatele, vykonává pro něj sjednanou práci doma v pracovní době, kterou si sám rozvrhuje. Ač toto ustanovení omezovalo místo výkonu práce na dálku pouze na domov zaměstnance, lze ho považovat za srovnatelný institut, který byl Evropskou radou a dalšími institucemi EU předpokládán. Kritérium omezující místo výkonu práce na dálku pouze na domov zaměstnance bylo z českého pracovního práva odstraněno ve chvíli, kdy dne 1. 1. 2007 vešel v účinnost zákon č. 262/2006 Sb., zákoník práce (dále jen „ZP“), který prostřednictvím ustanovení $\S 317$ splnil záměr modernizace organizace práce, resp. jeho pružných forem, a v jistých ohledech ho dokonce svou flexibilitou předčil.

Existence ustanovení, které umožňuje práci na dálku, je pouze prvním krokem. Dalším krokem je jeho začlenění do kontextu pracovního práva tak, aby byl v praxi funkční a nenarážel na regulaci, která jeho použitelnost devalvuje. $Z$ tohoto pohledu se české pracovní právo dosud nevyrovnalo s některými problémy. I když nutno dodat, že evropská snaha o regulaci v tomto neposkytla pomoc, spíše naopak.

\section{VÝKON ZÁVISLÉ PRÁCE DLE PODMÍNEK § 317 ZP}

V př́ípadě, že zaměstnanec vykonává závislou práci pro zaměstnavatele podle předem dohodnutých podmínek na místě, které vyhovuje povaze sjednané práce, které se však nenachází na pracovišti zaměstnavatele, a sám si rozvrhuje pracovní dobu, 4 jedná se o jednu z forem atypického pracovněprávního vztahu, který je upraven v ustanovení $§ 317 \mathrm{ZP}$. V případě, že jsou splněny všechny definiční znaky obsažené v ustanovení § 317 ZP, rídí se tento výkon závislé práce pravidly ZP s výjimkou aplikace některých ustanovení, a to:

- nevztahuje se na ni úprava rozvržení pracovní doby, prostojů ani přerušení práce způsobené nepř́źzivými povětrnostními vlivy (dle § 317 písm. a) ZP);

- př̌i jiných důležitých osobních překážkách v práci nepř́isluší zaměstnanci náhrada mzdy nebo platu, nestanoví-li prováděcí právní předpis jinak ( 199 odst. 2) nebo jde-li o náhradu mzdy nebo platu podle § 192 (dle § 317 písm. b) ZP);

- při ní nepř́śluší mzda nebo plat nebo náhradní volno za práci př̌sčas ani náhradní volno nebo náhrada mzdy anebo př́ílatek za práci ve svátek (dle § 317 písm. b) ZP).

Neaplikací těchto podmínek dochází k omezení ochranné funkce pracovního práva, které je však vyváženo flexibilitou, kterou zaměstnanec má v podobě možnosti sám si rozvrhnout pracovní dobu a vybrat místo, kde bude závislou práci vykonávat. Tato omezení jsou důležitá zvláště z pohledu zaměstnavatele. Nelze po zaměstnavateli spravedlivě požadovat, aby poskytoval např. náhradu mzdy v případě jiné důležité osobní překážky v práci, když si zaměstnanec může sám rozvrhnout, zda v době této překážky bude práci vykonávat nebo ji přesune na jiný čas.

4 BĚLINA, M. a kol. Zákoník práce: komentář. 2. vyd. Praha: C. H. Beck, 2015, s. 1248. 
Možnost kombinovaného výkonu práce,, 5 a to částečně mimo pracoviště zaměstnavatele a částečně na pracovišti zaměstnavatele, není zákonem omezena. Pravidla podle ustanovení $\S 317 \mathrm{ZP}$ se pak použijí pouze $\mathrm{v}$ případě práce mimo pracoviště zaměstnavatele.

\section{POJEM}

Výkon závislé práce dle podmínek § 317 ZP zákoník neoznačuje zvláštním pojmem. Ustanovení $\$ 317$ je zařazeno v ZP pod část třináctou - společná ustanovení, hlavu IX - zvláštní povaha práce některých zaměstnanců, vyloučení pracovněprávního vztahu a vysílání $\mathrm{k}$ výkonu práce na území jiného členského státu EU. K předmětnému ustanovení se váže první část názvu hlavy IX, tedy ZP výkon závislé práce dle podmínek § 317 ZP označuje: zvláštní povaha práce některých zaměstnanců.

V literatuře je výkon závislé práce dle podmínek § 317 ZP nejednotně označován různými pojmy. Setkáváme se s označeními: domácký pracovník, ${ }^{6}$ práce na dálku, distanční práce, práce doma, ${ }^{7}$ teleworking, homeworking ${ }^{8}$ a další.

Převážná většina užívaných pojmů v sobě zahrnuje označení tří možností výkonu práce. Výkon práce doma (domácký pracovník, práce doma, homeworking), výkon práce na jiném místě, než je pracoviště zaměstnavatele (práce na dálku, distanční práce), nebo práci prostřednictvím komunikace na dálku (teleworking).

Zákon č. 65/1965 Sb., zákoník práce, v ustanovení § 267 odst. 2 definoval pojem domáckých pracovníků jako osob nepracujících na pracovištích zaměstnavatele, ale podle podmínek dohodnutých v pracovní smlouvě pro něj vykonávajících sjednané práce doma v pracovní době, kterou si sami rozvrhnou. $V$ rámci rekodifikace pracovního práva se již podmínka výkonu práce doma a pojem domácký pracovník do ZP nedostal. Došlo tak k rozšriření možnosti na výkon práce i mimo domov zaměstnance, a tedy pojem domácký zaměstnanec byl překonán.

Práce prostřednictvím komunikace na dálku (telefonu, internetu apod.) je pro výkon závislé práce dle podmínek § 317 ZP typická, ale není podmínkou, protože si lze představit i situace, kdy pro práci nebude potřeba, např. kreativní, vědecké a další činnosti.

Nejpřesnějším pojmem pro výkon závislé práce dle podmínek § 317 ZP je výkon práce na jiném místě, než je pracoviště zaměstnavatele, tedy pojmy práce na dálku nebo distanční práce. Pro výkon závislé práce dle podmínek § 317 ZP bude v tomto článku používán pojem distanční práce, protože je nejpřesnější.

5 VYSOKAJOVÁ, M. a kol. Zákoník práce: komentáŕ. 5. vyd. Praha: Wolters Kluwer, 2015, s. 644.

6 BĚLINA, $c$. $d$., s. 1248. Autor př́slušné kapitoly komentáŕe doc. Štefko o tomto pojmu poznamenává, že vzhledem $\mathrm{k}$ vývoji tohoto tématu zjevně je nepřesný.

7 JAKUBKA, J. Atypické pracovněprávní vztahy. Práce a mzda: odborný časopis pro otázky odměnování, pracovního práva, personalistiky, kolektivního vyjednávání a pro sociální oblast. 2002, roč. 50, č. 4, s. 7; také ANDRAŠČĆIKOVÁ, M. a kol. Zákoník práce: prováděcí nařízení vlády a dalši souvisejicí předpisy: s komentářem k 1.1.2016. Olomouc: ANAG, 2016, s. 485.

8 JOUZA, L. Zákoník práce s komentářem: včetně aplikace občanského zákoníku. 3. aktual. vyd. Praha: BOVA POLYGON, 2008, s. 805. Tyto pojmy jsou užívány v praxi např. v personalistice, kde jsou řazeny mezi tzv. zaměstnanecké benefity (viz JOUZA, L. Průvodce zaměstnaneckými výhodami. Praha: BMSS-Start, 2007, s. 51). 


\section{DEFINICE ZÁVISLÉ PRÁCE A DISTANČNÍ PRÁCE}

Distanční práce je druhem atypického pracovněprávního vztahu, který se svou formou liší od klasického pojetí pracovněprávních vztahů, a i přes tuto skutečnost splňuje všechny znaky závislé práce.

Distanční práce předpokládá výkon práce mimo pracoviště zaměstnavatele, což ZP výslovně dovoluje formulací „,na pracovišti zaměstnavatele, poprípadě na jiném dohodnutém mistě “ (§ 2 odst. $2 \mathrm{ZP}){ }^{9}$ Podmínka, že si zaměstnanec rozvrhuje pracovní dobu sám, je také splněna, zákon určuje výkon závislé práce „,v pracovní době “ ( 2 odst. 2 ZP), o tom, kdo tuto dobu rozhoduje, nehovoří. V dalších ustanoveních ZP ukládá pravidla o rozvržení pracovní doby, ale právě tato ustanovení jsou výslovně zmíněna mezi těmi, která se $\mathrm{v}$ případě distanční práce neaplikují (\$317 písm. a) ZP). Závislá práce je vykonávána ,ve vztahu nadřízenosti zaměstnavatele a podřízenosti zaměstnance " ( 2 odst. $1 \mathrm{ZP})$. I přses vysokou míru flexibility a volnosti, kterou zaměstnanec $\mathrm{v}$ rámci distanční práce má, se stále jedná o vztah nadřízenosti a podřízenosti. Zaměstnavatel zůstává tím, kdo určuje, jaká práce bude vykonávána, jakým způsobem, a během ní může její podmínky měnit.

\section{MÍSTO VÝKONU PRÁCE, PRACOVIŠTĚ}

Místo výkonu práce je pro distanční práci klíčovým znakem. Ustanovení $\S 34$ odst. 1 písm. b) ZP určuje místo nebo místa výkonu práce jako jednu z podstatných náležitostí pracovní smlouvy. $\mathrm{V}$ př́ípadě distanční práce nelze toto pravidlo opomenout a místo nebo místa výkonu práce vymezit dostatečně určitě. Místo nebo místa nemusejí být nutně vymezena jen jako konkrétní adresy, ale i např. jako obec, kraj, Česká republika apod., v tomto ponechává zákon stranám pracovního poměru volnost. ${ }^{10}$ Určení místa nebo míst výkonu práce má pro distanční práci důležitý význam, protože určuje rozsah dispozičního oprávnění zaměstnance si určit, kde bude práci vykonávat. ${ }^{11} \mathrm{~V}$ př́ípadě výkonu práce na pracovišti zaměstnavatele má toto dispoziční oprávnění zaměstnavatel, v př́ípadě distanční práce však náleží zaměstnanci. ${ }^{12}$

V ustanovení § 317 ZP je místo výkonu práce zaměstnance definováno jako místo, které není pracovištěm zaměstnavatele. Zůstává otázkou, jakým způsobem specifikovat místo výkonu práce zaměstnance, který vykonává distanční práci.

9 V literatuře se setkáváme s různými označeními pro tuto situaci. Vhodně např. ,,v současné době se prostorový charakter pracovního závazku rozvolñuje“ (GALVAS, M. a kol. Pracovní právo. 2. dopl. a přepr. vyd. Brno: Masarykova univerzita, 2015, s. 20).

10 BĚLINA, c. d., s. 213.

11 ŠTEFKO, M. Vymezení závislé a nelegální práce. Praha: Univerzita Karlova, Právnická fakulta, 2013, s. 173.

12 Pokud má zaměstnanec vykonávající distanční práci dispoziční oprávnění pro výběr místa z okruhu míst definovaného v pracovní smlouvě a zároveň účel cesty nesleduje výkon práce, lze dovodit, že taková cesta není cestou v režimu $§ 34$ a ZP, a tedy zaměstnanci nevzniká nárok na náhrady cestovních výdajů podle $\S 152$ písm. b) ZP. 
Pracovištěm rozumíme místo, kde zaměstnanec podle pokynů zaměstnavatele vykonává pracovní úkoly. Pracoviště mohou být kdekoliv v rámci okruhu definovaném místem (místy) výkonu práce..$^{13} \mathrm{~V}$ př́ípadě distanční práce zaměstnanec bezpochyby vykonává závislou práci na pracovišti podle předem dohodnutých podmínek a vzhledem $\mathrm{k}$ tomu, že je ve vztahu podřízenosti vǔči zaměstnavateli, i podle jeho pokynů. Místo výkonu distanční práce tedy splňuje znaky a je pracovištěm. A jelikož místo nebo místa výkonu práce, která si zaměstnanec pro výkon práce zvolí, musí být v pracovní smlouvě specifikována, každé místo, které si zaměstnanec pro výkon distanční práce zvolí, je pracovištěm.

\section{BOZP NA DISTANČNÍM PRACOVIŠTI}

Základní povinností, kterou ZP ukládá zaměstnavatelům, je zajistit bezpečnost a ochranu zdraví zaměstnanců při práci (dále jen „BOZP“) s ohledem na rizika možného ohrožení jejich života a zdraví, která se týkají výkonu práce. ${ }^{14}$ Mezi jiným je zaměstnavatel povinen zajistit takové prostorové a konstrukční uspořádání a vybavení pracoviště, aby pracovní podmínky pro výkon práce zaměstnance odpovídaly všem bezpečnostním a hygienickým požadavkům..$^{15}$

$\mathrm{V}$ př́padech distanční práce nemůže tyto povinnosti zaměstnavatel opomenout, jelikož místo, které si zaměstnanec zvolí pro výkon pracovních úkolů, je pracovištěm. ${ }^{16}$ $\mathrm{V}$ praxi však mohou nastat situace, kdy tyto povinnosti zaměstnavatel nemůže $\mathrm{z}$ důvodu komplikovanosti, nebo dokonce v rozporu s jinými právními předpisy, dodržet.

Základní překážkou je, že zaměstnanec má dispoziční právo si zvolit v rámci místa nebo míst, kde bude práci vykonávat. $\mathrm{V}$ případě, že je místo výkonu práce sjednáno formou obce, zaměstnavatel v daný okamžik ani nemusí vědět, kde zaměstnanec práci vykonává. Př́íkladem může být zaměstnanec pracující prostřednictvím internetu v internetové kavárně. Zaměstnavatel tento problém může vyřešit předem dohodnutím podmínky, že zaměstnanec bude každé místo výkonu práce ohlašovat předem. Dalším problémem jsou omezené možnosti zaměstnavatele pro přizpůsobení podmínek na pracovišti, např. osvětlení. ${ }^{17}$ Př́kladem může být situace, kdy si zaměstnanec pro výkon distanční práce pronajme prostor $\mathrm{v}$ kancelářské budově. Pro zaměstnavatele je $\mathrm{v}$ takovém př́padě neekonomické, až nemožné, uzpůsobit každý takový prostor pro svého zaměstnance, aby splňoval všechny povinnosti vyplývající z BOZP.

Další povinností zaměstnavatele při zajišt'ování BOZP je přijímat opatření $\mathrm{k}$ předcházení rizik. ${ }^{18} \mathrm{~V}$ rámci čehož je zaměstnavatel povinen soustavně vyhledávat nebezpečné činitele a procesy pracovního prostředí a pracovních podmínek, zjištovat jejich

13 Rozsudek Nejvyššího soudu ze dne 26. 11. 2015, sp. zn. 21 Cdo 4596/2014.

14 Ustanovení \$ 101 odst. 1 ZP.

15 Ustanovení § 2 zák. č. 309/2006 Sb., zákon o zajištění dalších podmínek bezpečnosti a ochrany zdraví při práci.

16 Podobný výklad viz VYSOKAJOVÁ, c. d., s. 645.

17 Ustanovení § 2 odst. 1 písm. b) zák. č. 309/2006 Sb., zákon o zajiššení dalších podmínek bezpečnosti a ochrany zdraví při práci.

18 Ustanovení § 102 odst. 1 ZP. 
prríčiny a zdroje a na jejich základě vyhledávat a hodnotit rizika a přijímat opatření $\mathrm{k}$ jejich odstranění. A dále je povinen pravidelně kontrolovat úroveň BOZP, zejména stav výrobních a pracovních prostředků a vybavení pracovišt'. ${ }^{19}$ Je tedy možné dojít $\mathrm{k}$ výkladu, že je zaměstnavatel pro řádný výkon těchto povinností povinen se s každým pracovištěm seznámit a pravidelně na něm kontrolovat úroveň BOZP. ${ }^{20}$

Překážkou dodržování těchto povinností je v některých případech nemožnost vstupu zaměstnavatele na pracoviště distančně pracujícího zaměstnance. Pokud si zaměstnanec zvolí za místo výkonu práce své bydliště, které je chráněno právem na ochranu obydlí, ${ }^{21}$ a nesouhlasí se vstupem zaměstnavatele, což je zcela v souladu s právem, je pro zaměstnavatele nemožné splnit zákonem dané povinnosti. Tento problém nelze zcela vyř̌šit vzájemnou dohodou o udělení souhlasu se vstupem, protože nelze zaměstnance vymahatelně zavázat $\mathrm{k}$ tomu, aby zaměstnavatele $\mathrm{v}$ budoucnu pouštěl $\mathrm{k}$ pravidelným kontrolám úrovně $\mathrm{BOZP} v$ jeho bydlišti, nebot' je to $\mathrm{v}$ rozporu z principem ústavně chráněného práva. Zaměstnanec může dřive uvedený souhlas odvolat. ${ }^{22}$ Zaměstnavatel se tak dostává do situace, kdy se vystavuje nebezpečí sankcí ze strany nedodržení povinností vyplývajících z BOZP nebo sankcí za porušení ústavního práva nedotknutelnosti obydlí, které má přesahy $\mathrm{v}$ trestním právu. ${ }^{23}$

Jelikož zaměstnavatel nesmí přenášet riziko z výkonu závislé práce na zaměstnance,$^{24}$ uzavř̌ení jakékoliv dohody o přenosu povinností vyplývajících z BOZP, která by zaměstnavatele zprošt'ovala jeho povinností, není možné.

Zaměstnavatel má povinnost zajistit zaměstnancům poskytnutí první pomoci. ${ }^{25}$ Pokud distančně pracující zaměstnanec pracuje sám ve svém bydlišti, tuto povinnost není zaměstnavatel schopen vykonávat. Prvním problémem je, že se nemusí dozvědět o vzniku této potřeby poskytnout první pomoc, a dalším problémem je pak její efektivní poskytnutí $\mathrm{v}$ př́ípadě velké vzdálenosti mezi distančním pracovištěm a pracovišš̌m zaměstnavatele.

\section{PRACOVNÍ ÚRAZY NA DISTANČNÍM PRACOVIŠTI}

Pracovní úraz je poškození zdraví nebo smrt zaměstnance, došlo-li k nim nezávisle na jeho vůli krátkodobým, náhlým a násilným působením zevních vlivů při plnění pracovních úkolů nebo v prímé souvislosti s ním. ${ }^{26}$ Se vznikem pracovního úrazu právo spojuje naplnění kritérií: zaprvé, existence poškození na zdraví nebo smrt

19 Ustanovení § 102 odst. 3 ZP.

20 TOMŠEJ, J. Home-office a problematika bezpečnosti a ochrany zdraví při práci. In: PICHRT, J. MORÁVEK, J. (eds.). Atypická zaměstnání - cesta k vyšši zaměstnanosti? Praha: Wolters Kluwer, 2015, s. $150-151$.

21 Čl. 12 odst. 1 LZPS: „Obydlí je nedotknutelné. Není dovoleno do něj vstoupit bez souhlasu toho, kdo v něm bydli.“; Čl. 8 EÚLP: „Každý má právo na respektování svého soukromého a rodinného života, obydlí a korespondence."

22 TOMŠEJ, $c . d .$, s. 151.

23 Ustanovení § 178 zákona 40/2009 Sb., trestní zákoník.

24 Ustanovení $\$ 346$ b odst. 2 ZP.

25 Ustanovení § 103 odst. 1 písm. j) ZP.

26 Ustanovení § $271 \mathrm{k}$, odst. $1 \mathrm{ZP}$. 
zaměstnance, které vznikly při plnění pracovních úkolů nebo v přímé souvislosti s ním. Zadruhé, vznik škody, a zatřetí, príčcinná souvislost mezi pracovním úrazem a vznikem škody. Přičemž tyto znaky musí být splněny kumulativně. ${ }^{27}$ Nejvyšší soud dále vyložil, že o pracovní úraz se jedná nejen při plnění pracovních úkolů nebo v prŕmé souvislosti $\mathrm{s}$ nimi, ale i při činnosti konané $\mathrm{v}$ průběhu pracovního dne, které $\mathrm{v}$ přímém slova smyslu nemají souvislost s plněním pracovního úkolu, a zároveň však nevybočují z obvyklého rámce. ${ }^{28}$

Tento extenzivní výklad činností, při kterých může vzniknout pracovní úraz spolu s objektivní odpovědností aplikovaný na případy distanční práce, může způsobit, že téměř při jakékoliv činnosti distančně pracujícího zaměstnance může zaměstnavateli vzniknout odpovědnost za pracovní úraz. Zaměstnavatel totiž v případech distanční práce má jen omezenou kontrolu nad zaměstnancem, který např. vykonává distanční práci ve svém bydlišti.

V ustanovení § 270 a $\$ 271$ ZP definuje řadu možností liberace zaměstnavatele z odpovědnosti za pracovní úraz. $V$ případě, že zaměstnavatel prokáže existenci některého liberačního důvodu, zprostí se zcela nebo zčásti odpovědnosti za pracovní úraz zaměstnance. $V$ př́ípadě distanční práce má zaměstnavatel pouze omezenou možnost okolnosti liberačního důvodu zjistit, potažmo dokázat.

Pro zaměstnavatele je $\mathrm{v}$ př́ípadě distanční práce prakticky vyloučena možnost liberace $\mathrm{z}$ důvodu, pokud postižený zaměstnanec svým zaviněním porušil právní nebo ostatní předpisy, anebo pokyny k zajištění bezpečnosti a ochrany zdraví při práci, ačkoliv s nimi byl řádně seznámen a jejich znalost a dodržování byly soustavně vyžadovány a kontrolovány ( 270 odst. 1 písm. a) ZP). Možnosti řádného zajištění soustavného vyžadování a kontrolování BOZP na distančním pracovišti zaměstnance, např. doma nebo v kavárně, jsou vyloučeny.

Zaměstnavatel má jen málo možností, jak prokázat liberační důvod, že si zaměstnanec počínal v rozporu s obvyklým způsobem chování tak, že je zrěejmé, že ačkoliv neporušil právní nebo ostatní předpisy nebo pokyny $\mathrm{k}$ zajištění bezpečnosti a ochrany zdraví při práci, jednal lehkomyslně, přestože si musel vzhledem ke své kvalifikaci a zkušenostem být vědom, že si může způsobit újmu na zdraví ( $\$ 270$ odst. 2 písm. a) ZP). Jelikož je pro zaměstnavatele na některých distančních pracovištích, např. v bydlišti zaměstnance, nemožné monitorovat chování zaměstnance, je pro něj nemožné opatřit si o jeho lehkomyslnosti důkazní prostředky pro potencionální soudní rízení. Součinnost zaměstnanců se $\mathrm{v}$ těchto případech nedá očekávat. Překážky efektivního monitorování chování a činností zaměstnance na některých distančních pracovištích jsou v některých případech nejen právní důvody, ale i vysoké náklady na jejich realizaci.

27 Rozsudek Nejvyššího soudu ze dne 27. 10. 2009, sp. zn. 21 Cdo 2861/2008.

28 Rozsudek Nejvyššího soudu ze dne 4. 9. 2012, sp. zn. 21 Cdo 2141/2011. O této problematice také např. Rozsudek Nejvyššího soudu ze dne 12. 2. 2009, sp. zn. 21 Cdo 5060/2007: „Pro závěr, zda poškození $z$ draví, které zaměstnanec utrpěl při některé $z$ aktivit v rámci tzv. team-buildingu, müže být považováno za pracovní úraz, není rozhodujicí formální označení tohoto kurzu týmové spolupráce v př́slušných dokumentech, nýbrž vlastní obsahová náplň činnosti, při které zaměstnanec úraz utrpěl."“ 


\section{NÁKLADY A ODMĚŇOVÁNÍ}

Distanční práce je závislou prací, která je dle § 2 odst. 2 ZP vykonávána na náklady zaměstnavatele za mzdu, plat nebo odměnu. Tato skutečnost spolu s distančním charakterem práce přináší v aplikační praxi potíže. Pro zaměstnavatele, který má jen malou možnost monitorovat chování zaměstnance a může jen těžko kontrolovat, zda zaměstnanec, vykazující odpracování určitého počtu hodin a s tím spojené náklady, opravdu pracoval a účtované náklady pro práci skutečně využil. I přes existující nástroje v oborech, ve kterých díky jejich charakteru nelze přesně určit normu spotřeby práce, ${ }^{29}$ např. kreativní marketingové činnosti, IT vývojové činnosti apod., toto nelze jednoznačně určit.

Jedním z řešení vykazování vykonané práce může být úkolová mzda, ${ }^{30}$ kterou je možné sjednat při zachování pravidel stanovené týdenní pracovní doby dle § 79 ZP: zaměstnavatel nesmí přidělit více práce, než je zaměstnanec schopen odpracovat během této doby. Správné určení množství přidělené práce tak může být přesto problematické.

Výše a způsob poskytování náhrad za opotřebení vlastního vybavení, které zaměstnanec používá pro výkon závislé práce vyjma motorových vozidel, upravuje § 190 odst. 1 ZP. Vlastní vybavení zákon definuje jako nářadí, zařízení nebo jiné předměty potřebné $\mathrm{k}$ výkonu práce. Náhrada za opotřebení takového vybavení musí být tedy poskytnuta za předem dohodnutých, stanovených nebo určených podmínek. ${ }^{31} \mathrm{U}$ zařízení, jako je např. osobní počítač distančně pracujícího zaměstnance, na kterém je vykonávána závislá práce $\mathrm{v}$ kombinaci s osobními věcmi nebo prací pro jiného zaměstnavatele, lze jen těžko určit opotřebení v takové mîre, kterou by bylo možné přesně určit.

\section{ZÁVĚR}

Výkon závislé práce dle podmínek § 317 ZP, tedy výkon závislé práce zaměstnancem podle předem dohodnutých podmínek na místě, které vyhovuje povaze sjednané práce, které se však nenachází na pracovišti zaměstnavatele, a v pracovní době, kterou si zaměstnanec sám rozvrhuje, je jednou z forem atypického pracovněprávního vztahu, který je na trhu práce stále více využíván. Již od roku 2001 probíhá na evropské úrovni iniciativa, která má za cíl regulovat tento typ výkonu závislé práce tak, aby přispěl k udržení konkurenceschopnosti evropského trhu práce a pomohl k vyšší zaměstnanosti. České pracovní právo následuje tento trend. Tato forma atypického pracovněprávního vztahu existuje v kodexu českého pracovního práva již od 1. 1. 1966, kdy vešel v účinnost zákon č. 65/1965 Sb., zákoník práce (starý), který v ustanovení $\S 267$ odst. 2 upravoval tzv. domácké zaměstnance, tedy zaměstnance, kteří nepracují na

\footnotetext{
9 BĚLINA, $c . d .$, s. 1165.

30 Tamtéž, s. 1251.

31 Dle ustanovení $§ 16$ odst. 1 ZP zaměstnavatel musí poskytovat náhrady v rovné výši tak, aby nedocházelo k nerovnému zacházení mezi jednotlivými zaměstnanci, at’ už distančně pracujícími navzájem, nebo těmi na pracovišti zaměstnavatele.
} 
pracovišti zaměstnavatele (resp. organizace), ale doma. Toto omezení bylo odstraněno právě institutem výkon závislé práce dle podmínek § 317 ZP.

Pro výkon závislé práce dle podmínek $\$ 317$ ZP je užívána celá řada pojmů. Pojem distanční práce se zdá být nejpřiléhavějším, protože $\mathrm{v}$ sobě obsahuje podmínku, že práce je vykonávána mimo pracoviště zaměstnavatele bez dalších omezujících kritérií, což je v souladu s předmětných ustanovením ZP, který tento institut upravuje.

Klíčovým znakem pro distanční práci je místo výkonu práce, které je mimo pracoviště zaměstnavatele. Důležitou otázkou tedy je, jak z pohledu pracovního práva klasifikovat místo, kde zaměstnanec distanční práci vykonává. V souvislosti s tímto bylo judikováno, že pracovištěm rozumíme místo, kde zaměstnanec podle pokynů zaměstnavatele vykonává pracovní úkoly. Distančně pracující zaměstnanec bezpochyby vykonává pracovní úkoly dle pokynů zaměstnavatele, proto místo i mimo pracoviště zaměstnavatele bude pracovištěm. S touto skutečností se pojí celá řada problematických otázek.

Zaměstnavatel má ve vztahu k pracovišti, kde zaměstnanec vykonává závislou práci, řadu povinností. Základní povinností, kterou ZP ukládá zaměstnavatelům, je zajistit BOZP s ohledem na rizika možného ohrožení života a zdraví zaměstnanců, která se týkají výkonu práce. Konkrétně např. dle zák. č. 309/2006 Sb., zákon o zajištění dalších podmínek BOZP, musí zaměstnavatel zajistit takové prostorové a konstrukční uspořádání a vybavení pracoviště, aby pracovní podmínky pro výkon práce zaměstnance odpovídaly všem bezpečnostním a hygienickým požadavkủm. Navíc zaměstnavatel musí prrijímat opatření $\mathrm{k}$ předcházení rizik, tedy je povinen soustavně vyhledávat mimo jiného nebezpečné činitele, přijímat opatření $\mathrm{k}$ jejich odstranění a pravidelně kontrolovat úroveň BOZP. V situaci, kdy např. je distanční práce vykonávaná v bydlišti zaměstnance, má zaměstnavatel právní i praktické překážky své zákonem dané povinnosti splnit. Jedná se především o nemožnost vstupu zaměstnavatele do místa výkonu distanční práce, které je zároveň bydlištěm a které je chráněno právem na ochranu obydlí. Jelikož zaměstnavatel nesmí přenášet riziko z výkonu závislé práce na zaměstnance, ${ }^{32}$ uzavření jakékoliv dohody o přenosu povinností vyplývajících z BOZP, která by zaměstnavatele zproštovala jeho povinností, není možná. Z praktického hlediska je jen málo pravděpodobné, že by zaměstnavatel měnil bydliště zaměstnance, aby bylo v souladu se zákonnými požadavky. Vedle nesouhlasu zaměstnance jsou zde i ekonomické nevýhody takových opatření.

V případě pracovního úrazu v ustanovení $§ 270$ a $§ 271$ ZP je definována celá řada možností liberace zaměstnavatele z odpovědnosti za pracovní úraz. Jedním z nich je, že zaměstnanec si počínal v rozporu s obvyklým způsobem chování tak, že je zřejmé, že ačkoliv neporušil právní nebo ostatní předpisy anebo pokyny k zajištění bezpečnosti a ochrany zdraví při práci, jednal lehkomyslně, přestože si musel vzhledem ke své kvalifikaci a zkušenostem být vědom, že si může způsobit újmu na zdraví (§ 270 odst. 2 písm. a) ZP). V př́ípadě, že zaměstnavatel toto prokáže, zprostí se z části povinnosti nahradit škodu nebo nemajetkovou újmu. V některých typech distančních pracovišt' je pro zaměstnavatele nemožné monitorovat chování zaměstnance, a proto je pro něj značně obtížné prokázat některý z liberačních důvodů.

32 Ustanovení § 346 b odst. 2 ZP. 
Dalšími problémy v př́padě výkonu distanční práce jsou náklady a odměňování za vykonanou práci. Vzhledem $\mathrm{k}$ tomu, že $\mathrm{v}$ případech distanční práce zaměstnavatel není v přímém kontaktu se zaměstnancem jako v případech, kdy zaměstnanec vykonává práci na pracovišti zaměstnavatele, vyvstává otázka, jakým způsobem monitorovat a kontrolovat odvedenou práci a náklady s ní spojené.

Závěrem lze shrnout, že výše popsané problémy nejsou pro institut distanční práce blokační a nebrání jeho aplikaci, ale mohou v některých typech vykonávané práce způsobovat neochotu zaměstnavatelů tento institut využívat z důvodů nejistoty a zvýšených ekonomických nákladů. Lze předpokládat, že mírnější nastavení pravidel ohledně BOZP, pracovních úrazů nebo dalších s tímto tématem souvisejících by přispělo k větší ochotě zaměstnavatelů tento institut aplikovat.

Mgr. Jakub Hablovič

Právnická fakulta Západočeské univerzity v Plzni

JakubHablovic@seznam.cz 